\title{
The effect of pyruvate intake and aerobic exercise on the change of serum parameters and body composition in obese men
}

\author{
Hyun-Jung Cho, Il-Young Paik, Ji-Soo Kim, \& Dae-Eun Kim* \\ Yonsei University
}

\begin{abstract}
[Purpose] The aim of this study is to find how the pyruvate intake and aerobic exercise effect on the body composition, exercise performance ability, blood factor and obesity related hormone, and to verify the effect of pyruvate intake and aerobic exercise as an effective substance for obesity improvement. [Methods] This study selected 20 obese men in their twenties who has more BMI than $25 \mathrm{~kg} / \mathrm{m}^{2}$, and are applicable in $25 \%$ of the body fat, and randomly sampled group of 10 people for pyruvate intake and aerobic exercise (PYA), and 10 people for placebo intake and aerobic exercise (PLA). Intake of pyruvate and placebo was implemented for 10 weeks, $6 \mathrm{~g}$ a day, and aerobic exercise, treadmill exercise in the intensity of $50 \sim 60 \%$ 's target heart rate, was conducted for 10 weeks, 3 times a week, 60 minutes a day. To demonstrate the effect of pyruvate intake and aerobic exercise, all of the body composition, exercise performance ability, Lactate, and blood factor and hormone related to obesity were measured before and after the test in the same manner. [Results] The main results from this study are as follow; 1) In the case of body composition, in PYA, weight $(p<.01), \operatorname{BMI}(p<.05)$, body fat percentage $(p<.01)$, and body weight without fat $(p<.001)$ are reduced meaningfully. 2$)$ In the exercise performance ability increased significantly in both $\operatorname{PYA}(p<.01)$ and $\operatorname{PLA}(p<.001)$ for $\dot{\mathrm{VO}}_{2 \max }$, Also, in the case of distance during the exercise, $\operatorname{PYA}(p<.01)$ and $\operatorname{PLA}(p<.05)$ increased significantly in 15 minutes and $\operatorname{PYA}(p<.01)$ and PLA $(p<.05) 30$ minutes, but only in PYA from $45 \operatorname{minutes}(p<.01)$ to 60 minutes $(p<.05) 3)$ In case of Lactate, the significant decrease in PYA during stabilization and the significant increase in PYA after 30 minutes of exercise was not seen after 45 minutes 4 ) In the case of blood factor, HDL-C showed a meaningful decrease in $\operatorname{PLA}(p<.05)$ and Leptin showed a meaningful decrease in $\operatorname{PYA}(p<.001)$. [Conclusions] To sum up these results, it was more effective for the group of PYA which ingested pyruvate in improving obesity, even when the same aerobic exercise is conducted.
\end{abstract}

Key words: Obese, Pyruvate, Aerobic exercise, $\dot{\mathrm{VO}}_{2 \max }$ Lactate, Leptin

\section{서 론}

비만은 전 세계적인 보건 문제로서 당뇨병, 고혈압 그리고 암 등의 여러 가지 성인질환 유병률과 직접적인 연관성이 있다(Arroyo-Johnson \& Mincey, 2016). 국

논문 투고일 : 2019. 03. 13 .

논문 수정일 : 2019. 04. 21.

게재 확정일 : 2019. 05. 13.

* 교신저자 : 김대은(kde0528@hanmail.net).
내의 비만 인구 또한 꾸준하게 증가하고 있으며, 20 50대 비만 유병률은 체질량지수(body mass index: $\mathrm{BMI})$ 기준으로 남자가 여자보다 높고, 20대 남성의 비 만 유병률은 다른 연령에 비해 급격히 증가하는 것으로 나타났다(Ministry of Health and Welfare, 2015). 한편 비만 개선을 위한 다양한 방법으로는 칼로리 제 한요법, 행동수정요법, 수술요법, 약물요법, 그리고 운동 요법 등이 보고되었다(American College of Sports Medicine, 2010). 특히 장기간 중강도의 유산소 운동은 
지방 대사를 활성화시켜 체내의 지방조직 (adipose tissue)을 효과적으로 감소시키기 때문에 체중 관리를 위한 적절한 운동 방법으로 권장된다(McMurray et al., 2014). 한편 에너지 보충제 (ergogenic aids) 섭취는 운동시 체 내의 에너지 동원과 활용에 긍정적인 영향을 주며, 운동 과 함께 병행할 때 비만 개선에 더욱 효과적인 방법이 될 수 있다(Naderi et al., 2016).

특히 피루빈산(pyruvate)은 유·무산소 에너지 대사의 중간 산물이자 우리 몸에서 자연스럽게 생성되는 물질로 서, 에너지 소비량 증가와 체중 및 체지방 감소 등에 효과 가 있다고 보고되었다(Olek et al., 2014; Gong \& Jiang, 2018). 유산소 운동으로 산소 공급이 지속될 경우에는 pyruvate는 젖산(lactate)으로 변환되지 않고, 미토콘드 리아로 이동하여 피르부산 탈수효소(pyruvate dehydrogenase: $\mathrm{PDH}$ )에 의해 아세틸 보조 효소 A(acetyl coenzyme A)로 전환된다(Schell et al., 2014). 이러한 과정은 인체의 에너지인 아데노신 삼 인산(adenosine triphosphate: ATP)을 생성하는 대사 과정이며, 따라서 pyruvate는 에너지 생성에 매우 중요한 에너지 전구체 (precusor)이다(Gray et al., 2014). 장기간 pyruvate 섭취 와 유산소 운동을 병행할 시에는 지방 대사를 더욱 촉진 하며 (Koivisto et al., 2016), 장시간 운동을 지속할수 록 지방 동원 비율이 높아짐에 따라 비만 개선에도 더욱 긍정적인 효과를 가져올 수 있다(Lee et al., 2009).

한편, leptin은 비만 유전자 생성물로서 (Zhang et al., 1994) 일반적으로 정상 체중인 사람보다 비만인의 leptin 수치는 필요 이상으로 높게 나타나는데, 이러한 원인 은 비만으로 인해 증가된 지방조직이 혈중 leptin 수준을 증가시킴에 따라 leptin 저항성을 유발하고, 이는 과잉 섭취 및 에너지 소비 저하의 원인으로 보고된다(Banks et al, 2011; Wauman et al., 2017). 따라서 체지방 감 소를 통한 체중의 변화는 leptin 수치를 감소시키는데 효 과적인 방법으로 제시되고 있다(Park \& Ahima, 2015). 유산소 운동이 혈중 leptin 수준을 개선하고, 체지방 감 소나 유산소 능력을 향상시키고 심장질환을 감소시킨다 는 보고가 있으며 (Akbarpour, 2013) 특히 장기간의 유 산소 운동은 별다른 부작용 없이 leptin 수치를 긍정적 으로 개선시키는 것으로 보고되었다(Motamedi et al., 2017). 반면, pyruvate 섭취와 leptin의 변화를 알아본 연구는 매우 부족한 실정이다.

과거부터 쥐 또는 인간을 대상으로 pyruvate 효과를
규명한 연구에서도 신체구성의 변화, RMR의 증가, 그 리고 혈중 지질 개선 등의 긍정적인 결과가 보고되었다 (Cortez et al., 1991; Gong \& Jiang, 2018). Kalman et al.(1999)은 일반 성인을 대상으로 체중 및 체지방 감 소에 효과가 있는 pyruvate 섭취량을 하루 $6 \mathrm{~g} / \mathrm{d}$ 로 제시 하였으며, Koh-Banerjee et al. (2005)은 pyruvate 섭 취량을 하루 $5 \mathrm{~g} / \mathrm{d}$ 로 제시하고 있다. 그러나 대부분의 연 구가 단기간 운동 중 반응을 확인하였거나 단일 pyruvate 섭취만을 처치한 경우, 이미 체력 수준이 일반인보 다 우수한 운동선수를 대상으로 한 연구, 그리고 비교 가 능한 통제 그룹이 없는 연구들이었으며 (Morrison et al., 2000; Hermann et al., 2004), 주로 신체구성 및 혈중 지질 등의 변화를 확인하였다(Onakpoya et al., 2014). 특히 장기간의 pyruvate 보조제 섭취 및 운동 처치를 통 해 20 대 비만 남성의 대사량 및 비만 관련 호르몬 등의 변화를 알아본 연구는 매우 부족한 실정이다.

따라서 본 연구는 pyruvate 섭취와 유산소 운동 처치 가 20대 비만 남성의 신체구성, 운동수행능력, 그리고 혈액변인 및 비만 관련 호르몬인 leptin에 미치는 영향 에 대해 검증하여, 비만 개선에 효과적인 물질로서 pyruvate 섭취 효과 및 유산소 운동의 효과를 규명하고자 하였다.

\section{연구방법}

\section{연구대상}

본 연구의 대상자는 $\mathrm{Y}$ 대학교 학생 및 $\mathrm{S}$ 시 소재에 거 주하는 20 대 비만 남성으로서, $\mathrm{WHO}$ 가 보고한 아시아 태평양 기준으로 $\mathrm{BMI} 25 \mathrm{~kg} / \mathrm{m}^{2}$, 체지방률 (percent body fat: BF) $25 \%$ 이상인 자 총 20 명을 선정하였다. 사전 면담과 문진을 통해 연구에 대한 충분한 설명을 듣고 자 발적으로 참여하였으며, 의학적 질환이 없고, 최근 6 개월 내에 체계적인 운동 경력이 없는 자를 대상으로 하였다. 총 2그룹으로 pyruvate 섭취와 유산소 운동집단(pyruvate+aerobic exercise group: PYA), 위약 섭취와 유 산소 운동집단(placebo + aerobic exercise group: PLA) 으로 나누고, 각각 10명씩 무선할당(random assignment)하였다. 연구 대상자의 신체적 특성은 〈Table 1〉 과 같다. 
Table 1. Physical characteristics of participants

(Mean \pm SD)

\begin{tabular}{lcc}
\hline \hline \multirow{2}{*}{ Variable } & \multicolumn{2}{c}{ Group } \\
\cline { 2 - 3 } & PYA $(\mathrm{n}=10)$ & PLA $(\mathrm{n}=10)$ \\
\hline Age $(\mathrm{yrs})$ & $25.6 \pm 2.0$ & $25.3 \pm 2.8$ \\
\hline Height $(\mathrm{cm})$ & $179.7 \pm 7.3$ & $175.4 \pm 6.1$ \\
\hline Body weight $(\mathrm{kg})$ & $90.2 \pm 5.4$ & $87.0 \pm 2.6$ \\
\hline BMI $\left(\mathrm{kg} / \mathrm{m}^{2}\right)$ & $28.6 \pm 0.9$ & $28.0 \pm 1.1$ \\
\hline \%BF $(\%)$ & $28.6 \pm 3.8$ & $28.5 \pm 3.4$ \\
\hline Body fat mass $(\mathrm{kg})$ & $26.3 \pm 3.9$ & $26.5 \pm 6.8$ \\
\hline Lean body mass $(\mathrm{kg})$ & $36.5 \pm 2.8$ & $34.9 \pm 1.9$ \\
\hline \hline
\end{tabular}

PYA: pyruvate+aerobic exercise group,

PLA: placebo + aerobic exercise group,

BMI: body mass index, \%BF: percent body fat,

BFM: body fat mass, LBM: lean body mass.

\section{측정 항목 및 방법}

모든 대상자는 사전 검사로 기본 검사(신장, 체중, $\mathrm{BMI}$, 체지방률, 체지 방량(body fat mass: BFM), 제지 방량(lean body mass: $\mathrm{LBM}$ ), $\mathrm{VO}_{2 \max }$ )와 혈액 검사(중 성지방(triglycerides: TG), 총 콜레스테롤(total cholesterol: TC), 고밀도 지단백 콜레스테롤(high-density lipoprotein cholesterol: HDL-C), 저밀도 지단백 콜레 스테롤 (low-density lipoprotein cholesterol: LDL-C), Insulin, Glucose, homeostasis model of assessment of insulin resistance(HOMA-IR), leptin)를 실시하였 다. 10 주간 본 실험으로 각각 할당된 보조제 섭취 및 유산소 운동을 실시하였으며, 식이섭취와 생활습관에 있 어서는 변화로 인해 실험에 영향을 끼치지 못하도록 유 지하도록 하였다. 운동수행능력의 변화를 알아보기 위해 유산소 운동 시작 1 일차 및 유산소 운동 종료 2 일 전 총 2 회를 동일한 방법으로 혈액 변인인 lactate(안정시, 운 동 중 30 분, 45 분)와 운동수행능력과 관련된 변인인 운 동 중 거리( 15 분, 30 분, 45 분, 60 분)의 변화를 측정하였 다. 사후검사는 10 주간의 처치 후 사전 검사와 동일하게 실시하였다. 충분한 수면과 검사 하루 전과 당일 무리한 운동을 금하였으며, 검사 $12 \sim 48$ 시간 전 음식물 섭취를 제한하여 공복상태를 유지하였다. 또한 10 주간 본 연구 에서 제 공하는 보조제 섭취와 운동 운동 외에 결과에 영 향을 미칠 수 있는 기타 약물 복용이나 추가적인 신체활 동, 그리고 기타 요인 등은 최대한 통제시켰다. 측정 중
검사실 온도는 $20 \sim 23^{\circ} \mathrm{C}$, 습도는 $40 \sim 60 \%$ 를 유지하 였고, 충분한 안정을 취한 후 안전하게 검사를 실시하 였다.

\section{체격과 신체구성}

체격과 신체구성 변인으로는 신장, 체중, $\mathrm{BMI}$, 체지 방률, 체지방량, 그리고 제지방량을 측정하였다. 측정은 Y대학교 Fitness Center 운동검사실에서 실시하였으며, 신장과 체중은 비만도계(BSM330, Biospace, Korea) 로 측정하였고, BMI, 체지방률, 체지방량, 그리고 제지 방량은 생체전기저항법을 이용한 체성분측정기 ( $\mathrm{InBody}$ 720, Biospace, Korea)를 사용해 측정하였다. 측정 12 시간 전 물과 음식물 섭취를 제한하고 공복 상태에서 측 정하였으며, 전기저항에 영향을 미치는 요인을 최소화 하기 위하여 착용 중인 금속 액세서리를 제거하고 간편 한 복장 및 정면을 응시하며 양발이 전극 판에 위치하게 한 후 실시하였다. 사전 및 사후검사는 모두 동일한 방 법으로 측정하였다.

\section{혈액 채취 및 분석}

혈 액변인인 TG, TC, HDL-C, LDL-C, Insulin, Glucose, HOMA-IR, 그리고 leptin은 사전 검사 1회, 10 주간의 처치 (pyruvate 또는 위약 섭취와 유산소 운동) 종료 후에 사후 검사 1 회로 총 2 회를 실시하였다. 측정 48시간 전 음주와 과도한 신체활동을 자제하고, 12 시간 전부터 물과 음식물 섭취를 제한한 공복 상태로 아침 7 8시에 Y대학교 검사실에 도착하여 30 분간의 안정을 취 한 후 감염과 안전에 유의하며 혈액을 채취하였다. 상완 주정맥 (antecubital vein)에서 1회용 주사기로 $20 \mathrm{ml}$ 의 혈액을 채취하였고, 각 분석항목에 따라 항응고 처리 및 처리되지 않은 튜브에 넣어 $3,000 \mathrm{rpm}$ 으로 10 분간 원심 분리 시킨 후에 세포성분(cellular elements)을 제외한 혈장(plasma)과 혈청 (serum)을 뽑아 각각 보관 튜브에 넣고 (주) $\mathrm{G}$ 의료재단에 의뢰하여 다음과 같이 분석하였다.

지질 관련된 혈액 변인인 $\mathrm{TG}, \mathrm{TC}, \mathrm{HDL}-\mathrm{C}$, 그리고 LDL-C는 Cobas 8000(c702, Roche, Germany)를 이용 하여 Enzymatic Colorimetric Assay 검사 방법으로 분석 하였다. Glucose는 Cobas 8000(c702, Roche, Germany) 를 이용하여 Glucose HK Gen.3(Roche, Germany) kit를 사용해 Enzymatic reference method with hexokinase 검사 방법으로 분석하였다. Insulin은 Cobas 8000(e801, 
Roche, Germany)를 이용하여 Insulin(Roche, Germany) kit를 사용해 ECLIA(Electrochemiluminescence Immunoassay) 검사 방법으로 분석하였다. Insulin resistance 지표인 HOMA-IR은 공복인슐린(fasting plasma insulin: $\mathrm{FPI}$ 과 공복혈당 (fasting plasma glucose: $\mathrm{FPG}$ )을 이 용하여 다음의 공식에 대입한 후 산출하였다(Matthews et al., 1985).

HOMA-IR $=[\mathrm{FPI}(\mu \mathrm{U} / \mathrm{mL}) \times \mathrm{FPG}(\mathrm{mmol} / \mathrm{L})] / 22.5$

Leptin은 $\gamma$-counter(COBRA 5010 Quantum, PACKARD, USA)를 이용하여 Human Leptin RIA kit 를 사용해 RIA(Radioimmunoassay) 검사 방법으로 분 석하였다. 한편 유산소 운동수행능력의 변화를 알아보 기 위해 혈중 lactate 검사를 사전(유산소 운동 시작 1일 차)과 사후(유산소 운동 종료 2일 전) 모두 동일한 방법 으로 실시하였다. 트레드밀에서 총 60 분간 목표 심박수 (target heart rate: THR) 60\% 강도의 유산소 운동에서 (안정시, 운동 중 30 분, 45 분) 측정하였고, 우측 검지에 손끝 마디 단위(finger-tip) 방법으로 채혈 후 Accutrend BM Lactate(Roche, Germany) kit를 사용해 젖산측 정기(Accutrend ${ }^{\circledR}$ Plus, Roche Diagnostics GmbH, Germany)로 분석하였다.

\section{최대산소섭취량 측정}

심폐지구력의 변화를 알아보기 위해 Bruce protocol 에 따라 $\mathrm{VO}_{2 \max }$ 를 측정하였다(Bruce et al., 2004). 사전 및 사후 검사 시 신체계측과 혈액 채취를 완료하 고, 30 분 이상 충분한 휴식을 취한 후 Y대학교 Fitness Center 운동검사실에서 측정하였다. 트레드밀 (TM65, Quinton, USA)에서 심박수측정기(FT2, T31coded ${ }^{\mathrm{TM}}$, Polar, Finland)를 착용한 후 실시하였으며, 호기된 공 기는 가스분석기(TrueOne 2400, ParvoMedics, Sandy, Utah, USA)를 이용하여 분석하였다.

\section{운동수행능력 측정}

10 주간의 처치에 따른 두 집단의 중강도 유산소 운 동수행능력(THR 60\%)의 변화를 알아보기 위하여 운 동 중 거리 ( 15 분, 30 분, 45 분, 60 분)의 변화를 측정하 였으며, 사전(유산소 운동 시작 1일차)과 사후(유산소
운동 종료 2일 전) 동일한 방법으로 측정하였으며, 거리 는 대상자의 THR $60 \%$ 가 되도록 조절하여 treadmill 의 속도를 확인하여 ( 15 분, 30 분, 45 분, 60 분) 아래의 식 으로 계산하였다.

$$
\text { 거리 }(\mathrm{km})=\text { 속도 }(\mathrm{km} / \mathrm{h}) \times \text { 시간 }(\mathrm{h})
$$

\section{유산소 운동 방법}

본 연구의 10 주간 유산소 운동은 신체구성 개선 및 체 지방 감소를 목적으로 $\operatorname{ACSM}(2010)$ 과 Heyward \& Gibson(2014)에서 권고한 사항을 적용한 유산소 운동 을 주 3 회, 총 70 분 (준비운동 5 분, 본 운동 60 분, 정리운 동 5 분)간 두 집단 모두 동일하게 실시하였다. 운동 강 도는 예비심박수(heart rate reserve: HRR)에 의거하여 $\mathrm{THR}$ 을 추정하는 karvonen 공식 $(\mathrm{THR}=$ 최대심박수 안정시 심박수] * 운동 강도 + 안정시 심박수)을 대입해 $\mathrm{THR} 50 \sim 65 \%$ 의 강도로 설정하였고, 운동시 폴라(FT2, T31 coded ${ }^{\mathrm{TM}}$, Polar, Finland)를 착용하여 운동 강도와 심박수를 계속 확인하였다.

\section{Pyruvate 및 위약 섭취 방법}

본 연구의 pyruvate 섭취 용량은 체중 감소 효과를 보고 한 선행연구에 근거하여 1 일 $6 \mathrm{~g}$ 으로 설정하였다(Kalman et al., 1999). 또한 pyruvate(Calcium pyruvate, Now foods, USA)는 섭취가 용이한 캡슐형 제품, 임상연구에 사용된 제품, 그리고 위약 제조가 가능한 제품에 부합되 는 제품으로 제공하였다. 섭취 방법은 1 캡슐 당 $1.2 \mathrm{~g}$ 의 백색 캡슐형 pyruvate 보조제를 하루 5 캡슐씩 10 주간 매일 아침 공복 상태에서 섭취하도록 하였다. 처음 1 주 차 섭취시 이상 반응을 확인하고 연구 기간 동안 부작 용이 있을 시 섭취 중단 및 주의사항 등을 충분히 숙지 한 후 자발적으로 참여하도록 하였다. 위약 집단인 PLA 는 PYA와 외형상 크기, 색상, 그리고 용량 등이 모두 동 일한 pyruvate 위약을 제 공하였으며, 주성분은 다른 가 외변인 효과가 나타나지 않도록 위약 제조에 사용되는 섬 유소(microcrystalline cellulose, Taiwan)를 사용하였 다. 섭취 여부를 확인하기 위하여 pyruvate를 2 주 간격 으로 배분하고, 각각 동일한 형태의 휴대용 약통을 제공 하여 보관 및 섭취하도록 하였다. 


\section{자료처리 방법}

본 연구에서 얻은 모든 자료는 SPSS PC+ for Windows (version 23.0) 통계 프로그램을 이용해 분석하였다. 각 집단에서 얻은 종속변인의 기술 통계량을 평균(mean) 과 표준편차(standard deviation of mean: SD)로 제시 하였다. 두 집단(PYA, PLA)간, 두 검사(사전검사, 사후 검사)간 동질성 검증 후 종속변인의 평균 차이를 검증 하기 위해 반복 이원변량분석 (two-way ANOVA with repeated measures)을 실시하였다. 집단의 주효과, 검 사의 주효과, 또는 집단과 검사의 상호작용이 유의한 경 우 각 집단 내 두 검사 간 차이는 종속 $\mathrm{t}$-검증 (paired $\mathrm{t}$ test)으로 하였고, 각 검사 내 두 집단 간 차이는 독립 t검증 (independent t-test)으로 분석하였다. 모든 통계 분석의 유의수준 $(\alpha)$ 은 .05로 설정하였다.

\section{연구결과}

신체구성의 변화는 체지방률과 체지방량에서 시기의 주효과가 유의하게 나타났고, BMI에서 집단과 시기의 상호작용이 유의하게 나타났으며, 체중에서는 시기의 주 효과 및 집단과 시기의 상호작용이 유의하게 나타났다. $\mathrm{PYA}$ 에서 체중 $(p<.01), \mathrm{BMI}(p<.05)$, 체지방률 $(p<.01)$,
그리고 체지방량 $(p<.001)$ 이 유의하게 감소되었다 〈Table 2 참조〉.

운동수행능력의 변화는 $\mathrm{VO}_{2 \max }$ 와 운동 중 거리 15 분, 30 분, 45 분, 60 분에서 모두 시기의 주효과가 유의하게 나 타났다. $\mathrm{PYA}(p<.01)$ 와 $\mathrm{PLA}(p<.001)$ 에서 $\mathrm{VO}_{2 \max }$ 가 유 의하게 증가되었다. 또한 PYA에서 운동 중 15 분 $(p<$ $.01), 30$ 분 $(p<.01), 45$ 분 $(p<.01)$, 그리고 60 분 $(p<.05)$ 거리에서 모두 유의하게 증가되었으며, PLA에서 운동 중 15 분 $(p<.05)$ 과 30 분 $(p<.05)$ 거리에서 유의하게 증 가되었다<Table 3 참조〉.

Lactate의 변화는 안정시에서 집단과 시기의 상호작 용이 유의하게 나타났다. 운동 중 30 분에는 집단과 시기 의 주효과 및 집단과 시기의 상호작용이 유의하게 나타 났으며, 집단 간의 차이는 시기에서 PYA 보다 PLA가 유 의하게 낮은 것으로 나타났다. PYA에서 안정시 $(p<.001)$ 에 유의하게 감소하였으며, 운동 중 30 분 $(p<.001)$ 에는 유의하게 증가되었다〈Table 4 참조〉.

혈 액변인의 변화는 $\mathrm{HDL}-\mathrm{C}$ 에서 집단과 시기의 상호 작용이 유의하게 나타났으며, leptin에서 시기의 주효과 및 집단과 시기의 상호작용이 유의하게 나타났다. PLA 에서 $\mathrm{HDL}-\mathrm{C}(p<.05)$ 가 유의하게 감소되었으며, $\mathrm{PYA}$ 에서 $\operatorname{Leptin}(p<.001)$ 이 유의하게 감소되었다<Table 5 참조〉.

Table 2. Changes of physique and body composition

$($ Mean \pm SD)

\begin{tabular}{|c|c|c|c|c|c|c|c|}
\hline \multirow{2}{*}{ Variables } & \multirow{2}{*}{ Groups } & \multicolumn{2}{|c|}{ Tests } & & \multirow{2}{*}{$\Delta \%$} & & \multirow{2}{*}{$\mathrm{P}$} \\
\hline & & Pre & Post & & & & \\
\hline \multirow{2}{*}{$\begin{array}{l}\text { Body Weight } \\
\text { (kg) }\end{array}$} & PYA & $90.2 \pm 5.4$ & $87.2 \pm 6.2$ & $* *$ & -3.40 & \multirow{2}{*}{$\begin{array}{c}\mathrm{G} \\
\mathrm{T} \\
\mathrm{G} \times \mathrm{T}\end{array}$} & \multirow{2}{*}{$\begin{array}{l}.400 \\
.036+ \\
.014+\end{array}$} \\
\hline & PLA & $87.0 \pm 2.6$ & $87.3 \pm 0.8$ & & 0.33 & & \\
\hline \multirow{2}{*}{$\begin{array}{l}\text { Body mass index } \\
\left(\mathrm{kg} / \mathrm{m}^{2}\right)\end{array}$} & PYA & $28.6 \pm 0.9$ & $27.7 \pm 1.3$ & $*$ & -3.32 & \multirow{2}{*}{$\begin{array}{c}\mathrm{G} \\
\mathrm{T} \\
\mathrm{G} \times \mathrm{T}\end{array}$} & \multirow{2}{*}{$\begin{array}{l}.744 \\
.802 \\
.049+\end{array}$} \\
\hline & PLA & $28.0 \pm 1.1$ & $28.8 \pm 2.8$ & & 2.66 & & \\
\hline \multirow{2}{*}{$\begin{array}{l}\text { Percent body fat } \\
(\%)\end{array}$} & PYA & $28.6 \pm 3.8$ & $26.1 \pm 4.0$ & $* *$ & -8.65 & \multirow{2}{*}{$\begin{array}{c}\mathrm{G} \\
\mathrm{T} \\
\mathrm{G} \times \mathrm{T}\end{array}$} & \multirow{2}{*}{$\begin{array}{l}.594 \\
.032 \\
.161\end{array}$} \\
\hline & PLA & $28.5 \pm 3.4$ & $28.0 \pm 4.9$ & & -1.98 & & \\
\hline \multirow{2}{*}{$\begin{array}{l}\text { Body fat mass } \\
(\mathrm{kg})\end{array}$} & PYA & $26.3 \pm 3.9$ & $23.4 \pm 3.9$ & $* * *$ & -11.05 & \multirow{2}{*}{$\begin{array}{c}\mathrm{G} \\
\mathrm{T} \\
\mathrm{G} \times \mathrm{T}\end{array}$} & \multirow{2}{*}{$\begin{array}{l}.713 \\
.000+1+1 \\
.137\end{array}$} \\
\hline & PLA & $26.5 \pm 6.8$ & $25.1 \pm 6.6$ & & -5.54 & & \\
\hline \multirow{2}{*}{$\begin{array}{l}\text { Lean body mass } \\
(\mathrm{kg})\end{array}$} & PYA & $36.5 \pm 2.8$ & $36.5 \pm 3.3$ & & -0.01 & \multirow{2}{*}{ 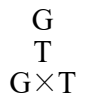 } & \multirow{2}{*}{$\begin{array}{l}.223 \\
.393 \\
.388\end{array}$} \\
\hline & PLA & $34.9 \pm 1.9$ & $35.2 \pm 1.9$ & & 1.02 & & \\
\hline
\end{tabular}

PYA: pyruvate+aerobic exercise group, PLA: placebo+aerobic exercise group, G: group, T: time, G $\times$ T: group $\times$ time ${ }^{+}<.05,{ }^{++}<.001$ : Significant main effect or interaction,

${ }^{*}<.05, * * 01,{ }^{* * *}<.001$ : Significant difference between pre and post test within a group. 
Table 3. Changes of exercise performance ability

$(\mathrm{Mean} \pm \mathrm{SD})$

\begin{tabular}{|c|c|c|c|c|c|c|c|}
\hline \multirow{2}{*}{ Variables } & \multirow{2}{*}{ Groups } & \multicolumn{2}{|c|}{ Tests } & & \multirow{2}{*}{$\Delta \%$} & & \multirow{2}{*}{$\mathrm{P}$} \\
\hline & & Pre & Post & & & & \\
\hline \multirow{2}{*}{$\begin{array}{l}\mathrm{VO}_{2 \max } \\
(\mathrm{ml} / \mathrm{kg} / \mathrm{min})\end{array}$} & PYA & $32.5 \pm 4.1$ & $36.6 \pm 4.4$ & $* *$ & 12.58 & \multirow{2}{*}{$\underset{\mathrm{G}}{\mathrm{G}}$} & \multirow{2}{*}{$\begin{array}{l}.726 \\
.000^{+1+} \\
.593\end{array}$} \\
\hline & PLA & $33.8 \pm 7.6$ & $37.2 \pm 6.8$ & $* * *$ & 10.28 & & \\
\hline \multirow{2}{*}{$\begin{array}{l}\text { Distance during the exercise of } \\
15 \text { minutes }(\mathrm{km})\end{array}$} & PYA & $1.8 \pm 0.2$ & $1.9 \pm 0.2$ & $* *$ & 12.09 & \multirow{2}{*}{$\begin{array}{c}\mathrm{G} \\
\mathrm{T} \\
\mathrm{G} \times \mathrm{T}\end{array}$} & \multirow{2}{*}{$\begin{array}{l}.721 \\
.001^{++1} \\
.931\end{array}$} \\
\hline & PLA & $1.7 \pm 0.2$ & $1.9 \pm 0.2$ & $*$ & -0.84 & & \\
\hline \multirow{2}{*}{$\begin{array}{l}\text { Distance during the exercise of } \\
30 \text { minutes }(\mathrm{km})\end{array}$} & PYA & $3.5 \pm 0.4$ & $4.1 \pm 0.6$ & ** & 9.01 & \multirow{2}{*}{$\begin{array}{c}\mathrm{G} \\
\mathrm{T} \\
\mathrm{G} \times \mathrm{T}\end{array}$} & \multirow{2}{*}{$\begin{array}{l}.150 \\
.000^{+1} \\
.874\end{array}$} \\
\hline & PLA & $3.2 \pm 0.9$ & $3.8 \pm 0.5$ & $*$ & 9.60 & & \\
\hline \multirow{2}{*}{$\begin{array}{l}\text { Distance during the exercise of } \\
45 \text { minutes }(\mathrm{km})\end{array}$} & PYA & $5.4 \pm 0.5$ & $6.2 \pm 0.9$ & $* *$ & 18.47 & \multirow{2}{*}{$\begin{array}{c}\mathrm{G} \\
\mathrm{T} \\
\mathrm{G} \times \mathrm{T}\end{array}$} & \multirow{2}{*}{$\begin{array}{l}.096 \\
.002^{++} \\
.973\end{array}$} \\
\hline & PLA & $4.8 \pm 1.3$ & $5.7 \pm 0.6$ & & 18.91 & & \\
\hline \multirow{2}{*}{$\begin{array}{l}\text { Distance during the exercise of } \\
60 \text { minutes }(\mathrm{km})\end{array}$} & PYA & $6.8 \pm 0.5$ & $7.3 \pm 0.8$ & * & 15.75 & \multirow{2}{*}{$\underset{\mathrm{G} \times \mathrm{T}}{\mathrm{G}}$} & \multirow{2}{*}{$\begin{array}{l}.399 \\
.026^{+} \\
.575\end{array}$} \\
\hline & PLA & $6.3 \pm 1.5$ & $7.1 \pm 1.0$ & & 17.99 & & \\
\hline
\end{tabular}

PYA: pyruvate+aerobic exercise group, PLA: placebo+aerobic exercise group, G: group, T: time, G $\times$ T: group $\times$ time

${ }^{+}<.05,{ }^{++}<.001$ : Significant main effect or interaction,

* $<.05,{ }^{* *}<.01,{ }^{* *}<.001$ : Significant difference between pre and post test within a group.

Table 4. Changes of lactate

$(\mathrm{Mean} \pm \mathrm{SD})$

\begin{tabular}{|c|c|c|c|c|c|c|c|}
\hline \multirow{2}{*}{ Variables } & \multirow{2}{*}{ Groups } & \multicolumn{2}{|c|}{ Tests } & \multirow{2}{*}{\multicolumn{2}{|c|}{$\Delta \%$}} & & \multirow{2}{*}{$\mathrm{P}$} \\
\hline & & Pre & Post & & & & \\
\hline \multirow{2}{*}{$\begin{array}{l}\text { Lactate of when it is stable } \\
(\mathrm{mmol} / \ell)\end{array}$} & PYA & $2.6 \pm 0.5$ & $1.3 \pm 0.2$ & *** & -48.74 & \multirow{2}{*}{$\begin{array}{c}\mathrm{G} \\
\mathrm{T} \\
\mathrm{G} \times \mathrm{T}\end{array}$} & \multirow{2}{*}{$\begin{array}{l}.550 \\
.000^{++1+} \\
.002^{++}\end{array}$} \\
\hline & PLA & $2.3 \pm 0.2$ & $1.9 \pm 0.6$ & & -18.65 & & \\
\hline \multirow{2}{*}{$\begin{array}{l}\text { Lactate during the exercise of } \\
30 \text { minutes }(\mathrm{mmol} / \ell)\end{array}$} & PYA & $4.8 \pm 1.5$ & $11.9 \pm 4.7$ & *** & 147.00 & \multirow{2}{*}{$\begin{array}{c}\mathrm{G} \\
\mathrm{T} \\
\mathrm{G} \times \mathrm{T}\end{array}$} & \multirow{2}{*}{$\begin{array}{l}.001^{+++} \\
.000^{++1} \\
.001^{+1+}\end{array}$} \\
\hline & PLA & $3.6 \pm 0.9^{\#}$ & $4.9 \pm 1.9^{\#}$ & & 37.53 & & \\
\hline \multirow{2}{*}{$\begin{array}{l}\text { Lactate during the exercise of } \\
45 \text { minutes }(\mathrm{mmol} / \ell)\end{array}$} & PYA & $6.1 \pm 1.3$ & $5.8 \pm 2.7$ & & -5.27 & \multirow{2}{*}{$\underset{\mathrm{G}}{\mathrm{G}}$} & \multirow{2}{*}{$\begin{array}{l}.927 \\
.978 \\
.646\end{array}$} \\
\hline & PLA & $5.8 \pm 2.1$ & $6.1 \pm 1.9$ & & 4.85 & & \\
\hline
\end{tabular}

PYA: pyruvate+aerobic exercise group, PLA: placebo+aerobic exercise group, G: group, T: time, G $\times \mathrm{T}$ : group $\times$ time $++\langle .01,+++\langle .001$ : Significant main effect or interaction,

$* * *<.001$ : Significant difference between pre and post test within a group.

\#: The difference between the two groups.

\section{논 의}

규칙적인 유산소 운동을 통한 신체활동 증가는 신체 구성 개선과 심폐지구력 향상 등의 효과가 보고되었다 (Swift et al., 2014). 또한 비만 개선에 도움을 주는 ergogenic aids을 함께 섭취할 시에는 체내 빠른 에너지 생 성과 공급을 통해 운동수행능력의 향상으로 체중 감소 에 더욱 큰 효과를 기대할 수 있다(Saper et al., 2004). 본 연구에서는 20 대 비만 남성을 대상으로 10 주간 pyruvate 및 위약 섭취와 유산소 운동을 실시하였다. 신체구
성의 변화는 10 주간의 처치 후 PYA에서 체중 $(3.4 \%$ 감 소)과 $\mathrm{BMI}(3.32 \%$ 감소)의 유의한 변화가 나타났으며, 체지방률과 체지 방량은 유의한 변화가 나타나지 않았으 나 시기의 주효과가 유의하게 나타나 체지방률 $(8.65 \%$ 감소)과 체지방량 $(11.05 \%$ 감소)의 변화가 나타난 것을 보았을 때 사전보다 신체구성의 변화에 긍정적인 결과 를 가져왔다고 사료된다. 한편 제지방량은 두 집단 모두 유의한 변화가 없었으며, 이는 유산소 운동이 골격근량의 증가 보다 신체구성의 개선이나 에너지대사 활성화 등이 주된 목적이기 때문이다(Roberts et al., 2013). 이러한 
Table 5. Changes of blood factor and obesity related hormone

$(\mathrm{Mean} \pm \mathrm{SD})$

\begin{tabular}{|c|c|c|c|c|c|c|c|}
\hline \multirow{2}{*}{ Variables } & \multirow{2}{*}{ Groups } & \multicolumn{2}{|c|}{ Tests } & \multirow{2}{*}{\multicolumn{2}{|c|}{$\Delta \%$}} & & \multirow{2}{*}{$\mathrm{P}$} \\
\hline & & Pre & Post & & & & \\
\hline \multirow{2}{*}{$\begin{array}{l}\mathrm{TG} \\
(\mathrm{mg} / \mathrm{dl})\end{array}$} & PYA & $117.2 \pm 34.2$ & $107.4 \pm 29.0$ & & -8.36 & \multirow{2}{*}{$\begin{array}{c}\mathrm{G} \\
\mathrm{G} \times \mathrm{T}\end{array}$} & \multirow{2}{*}{$\begin{array}{l}.43 \\
.65 \\
.573\end{array}$} \\
\hline & PLA & $124.8 \pm 49.8$ & $126.0 \pm 52.8$ & & 0.96 & & \\
\hline \multirow{2}{*}{$\begin{array}{l}\mathrm{TC} \\
(\mathrm{mg} / \mathrm{dl})\end{array}$} & PYA & $196.1 \pm 30.0$ & $184.7 \pm 22.3$ & & -5.81 & \multirow{2}{*}{$\begin{array}{c}\mathrm{G} \\
\mathrm{T} \\
\mathrm{G} \times \mathrm{T}\end{array}$} & \multirow{2}{*}{$\begin{array}{l}.78 \\
.53 \\
.10^{\prime}\end{array}$} \\
\hline & PLA & $185.4 \pm 20.0$ & $190.6 \pm 15.3$ & & 2.80 & & \\
\hline \multirow{2}{*}{$\begin{array}{l}\text { HDL-C } \\
(\mathrm{mg} / \mathrm{dl})\end{array}$} & PYA & $53.4 \pm 13.5$ & $54.4 \pm 14.4$ & & 1.87 & \multirow{2}{*}{$\begin{array}{c}\mathrm{G} \\
\mathrm{T} \\
\mathrm{G} \times \mathrm{T}\end{array}$} & \multirow{2}{*}{$\begin{array}{l}.25 \\
.17 \\
.04\end{array}$} \\
\hline & PLA & $50.4 \pm 9.4$ & $45.8 \pm 6.1$ & $*$ & -9.13 & & \\
\hline \multirow{2}{*}{$\begin{array}{l}\text { LDL-C } \\
(\mathrm{mg} / \mathrm{dl})\end{array}$} & PYA & $128.5 \pm 28.1$ & $121.1 \pm 17.6$ & & -5.76 & \multirow{2}{*}{$\begin{array}{c}\mathrm{G} \\
\mathrm{T} \\
\mathrm{G} \times \mathrm{T}\end{array}$} & \multirow{2}{*}{$\begin{array}{l}.880 \\
.36 \\
.638\end{array}$} \\
\hline & PLA & $127.5 \pm 30.7$ & $125.1 \pm 20.5$ & & -1.88 & & \\
\hline \multirow{2}{*}{$\begin{array}{l}\text { Insulin } \\
(\mu \mathrm{U} / \mathrm{ml})\end{array}$} & PYA & $10.9 \pm 3.4$ & $10.8 \pm 4.0$ & & -1.36 & \multirow{2}{*}{$\begin{array}{c}\mathrm{G} \\
\mathrm{T} \\
\mathrm{G} \times \mathrm{T}\end{array}$} & \multirow{2}{*}{$\begin{array}{l}.60 \\
.168 \\
.21\end{array}$} \\
\hline & PLA & $13.1 \pm 5.8$ & $10.4 \pm 3.6$ & & -20.46 & & \\
\hline \multirow{2}{*}{$\begin{array}{l}\text { Glucose } \\
(\mathrm{mg} / \mathrm{dl})\end{array}$} & PYA & $97.5 \pm 9.9$ & $96.0 \pm 7.4$ & & -1.54 & \multirow{2}{*}{$\begin{array}{c}\mathrm{G} \\
\mathrm{T} \\
\mathrm{G} \times \mathrm{T}\end{array}$} & \multirow{2}{*}{$\begin{array}{l}.25 \\
.74 \\
.148\end{array}$} \\
\hline & PLA & $92.5 \pm 3.8$ & $94.9 \pm 1.7$ & & 2.54 & & \\
\hline \multirow{2}{*}{ HOMA-IR } & PYA & $2.7 \pm 1.0$ & $2.5 \pm 0.9$ & & -4.90 & \multirow{2}{*}{$\begin{array}{c}\mathrm{G} \\
\mathrm{T} \\
\mathrm{G} \times \mathrm{T}\end{array}$} & \multirow{2}{*}{$\begin{array}{l}.740 \\
.122 \\
.29\end{array}$} \\
\hline & PLA & $3.1 \pm 1.4$ & $2.4 \pm 0.8$ & & -21.51 & & \\
\hline \multirow{2}{*}{$\begin{array}{l}\text { Leptin } \\
\text { (ng/ml) }\end{array}$} & PYA & $15.9 \pm 7.2$ & $10.7 \pm 5.8$ & $* * *$ & -32.64 & \multirow{2}{*}{$\begin{array}{c}\mathrm{G} \\
\mathrm{T} \\
\mathrm{G} \times \mathrm{T}\end{array}$} & \multirow{2}{*}{$\begin{array}{l}.755 \\
.000 \\
.049\end{array}$} \\
\hline & PLA & $15.2 \pm 6.2$ & $13.2 \pm 6.0$ & & -13.59 & & \\
\hline
\end{tabular}

PYA: pyruvate+aerobic exercise group, PLA: placebo+aerobic exercise group, G: group, T: time, G $\times \mathrm{T}$ : group $\times$ time $+\langle .05,+++\langle .001$ : Significant main effect or interaction,

${ }^{*}<.05,{ }^{* * *}<.001$ : Significant difference between pre and post test within a group.

결과는 pyruvate 섭취와 운동시 통제군보다 pyruvate 섭취군에서 운동수행능력의 향상과 지방 대사 촉진에 따 른 체중 및 체지방 감소를 보고한 선행연구(Kalman et al., 1999; Koivisto et al., 2016; Gong \& Jiang, 2018) 의 결과와 일치하였다. Ledee et al. (2015)은 체내 충분 한 양의 pyruvate가 축적되면 장시간 운동시 지방 동원 비율이 증가되며, 상대적으로 glycogen 절약 효과가 나 타남에 따라 운동수행능력의 향상을 가져와 유산소 대 사의 활성화를 통해 체중 및 체지방의 감소에도 긍정적인 영향을 미칠 수 있다고 보고하였다. Lundsgaard et al. (2017)은 중강도 유산소 운동으로 TG가 효소 lipase에 의하여 유리지방산(free fatty acid: FFA)으로 분해되고 운동시 주 에너지원으로 동원되는데, 장시간 오래 지속될 수록 지방 대사가 더욱 활성화되어 체중 및 신체구성의 변화에 긍정적인 영향을 미친다고 보고하였다. 종합해 보면, 10 주간 중강도 유산소 운동을 동일하게 실시한 두 집단 모두 운동 강도는 지방 산화비율이 가장 높다고 보
고된 $50 \sim 65 \%$ 강도로 장시간 실시하여 운동시 지 방이 주 에너지원으로 사용되었을 것이며, 제지방량에는 유의 한 영향을 미치지 못하였지만 신체구성 개선에 긍정적인 영향을 미쳤다고 할 수 있다. 특히 동일한 운동 조건에서 도 PYA는 pyruvate 섭취로 인해 운동시 지방 동원 비율 이 증가하고, 장시간 지방 대사가 활성화되어 PLA보다 더욱 긍정적인 효과가 나타났다고 판단된다.

유산소 운동수행능력의 변화를 알아보기 위해 10 주 간의 처치 후 $\mathrm{VO}_{2 \max }$ 는 두 집단 모두 유의한 변화가 나타 나지 않았으나 시기의 주효과가 유의하게 나타나 PYA (12.58\% 증가)와 $\operatorname{PLA}(10.28 \%$ 증가)의 변화가 나타났 다. 이러한 결과는 중강도 이상의 유산소 운동을 규칙적 으로 실시할 때 $\mathrm{VO}_{2 \max }$ 향상에 효과적이라고 보고된 바 있다(Milanović et al., 2015). 특히 평소 규칙적인 운동 을 실시하지 않는 과체중 및 비만인을 대상으로 실시할 경우 더욱 효과적일 수 있다고 보고되었다(Nybo et al., 2010). 또한 pyruvate 섭취와 유산소 능력의 증가를 알 
아본 연구에서도 pyruvate 섭취는 지방 대사의 활성화 및 유산소 운동수행능력 향상에 긍정적인 영향을 미칠 수 있다고 보고된 바 있으며 (Diers et al., 2012), 본 연구의 PYA가 PLA보다 증가한 결과는 선행연구를 지지하는 결 과가 될 수 있다. 두 집단의 $\mathrm{VO}_{2 \max }$ 에 유의한 영향을 미치 지 못한 이유는 연구의 대상이 비만 기준에 속했다할지 라도 젊은 20 대 남성을 대상으로 하였기 때문에 큰 효과 가 나타나기에는 다소 짧은 기간일 수 있었으며, 체력 수준이 좋아짐에 따라 중강도 유산소 운동이 비교적 낮은 운동 강도였을 수 있었다고 사료된다. 그러나 평상시 대 부분의 시간을 좌식 생활로 보내고 특별한 신체활동을 하 지 않았던 비만 남성에게 $\mathrm{VO}_{2 \max }$ 증가가 나타난 결과는 장기적으로 체력 및 심폐지구력 증가 등에 긍정적인 영 향을 미칠 수 있다는 점에서 매우 중요한 의미가 있다. 한 편 운동 중 거리는 15 분, 30 분, 45 분, 60 분을 측정하였 다. 두 집단 모두 운동 중 15 분과 30 분 거리에서 시기의 주효과가 유의하게 나타나 PYA에서 운동 중 15 분 거리 (9.01\% 증가), 30 분 거리 ( $18.47 \%$ 증가)의 변화가 나타 났으며, PLA에서 운동 중 15 분 거리(9.60\% 증가), 30 분 거리 ( $18.91 \%$ 증가)의 변화가 나타났다. 그러나 운동 시간이 길어질수록 운동 중 45 분과 60 분 거리에서는 시 기의 주효과가 유의하게 나타나 PYA에서 운동 중 45 분 거리( $15.75 \%$ 증가), 60 분 거리( $7.14 \%$ 증가)의 변화가 나타났다. 운동 시간이 길어질수록 무산소성 에너지 대사 비중이 높아지며 장시간 운동 수행을 위해서는 피로 시점 을 지연시키는 것이 매우 중요하다(Billat \& Koralsztein, 1996). 본 연구는 장시간 유산소 운동으로 지방 동원이 증가하고 glycogen 절약 효과로 피로 시점을 지연시켜 운동수행능력이 향상되어 두 집단 모두 운동 중 15 분과 30 분의 거리가 사전 보다 증가하는데 긍정적인 영향을 주었다고 판단된다(Spradley et al., 2012). PYA는 체 내 pyruvate가 축적되었을 것이며, 운동 시간이 길어질 수록 PLA보다 피로 시점을 더욱 지연시켜 동일한 유산 소 운동 조건에서도 운동수행능력이 더욱 향상된 결과라 고 본다. 종합해보면, 추후 연구로 더욱 긴 기간 동안 pyruvate 섭취와 인터벌 운동 등의 고강도 유산소 운동 등 을 통해 운동수행능력의 큰 향상을 가져올 수 있다고 사 료된다.

체내 높은 수준으로 생성된 lactate는 피로를 유발하 며 운동의 지속과 중단을 결정하는 운동수행능력의 지표 가 될 수 있다(Gladden, 2004). 운동시 지속적으로 산소
가 공급 될 때 lactate는 간과 근육에서 glucose로 재합성 되며, 다시 유용한 에너지원으로 사용된다(Proia et al., 2016). 본 연구에서 운동수행능력의 지표라고 할 수 있 는 혈중 lactate 농도는 PYA의 안정시 ( $48.74 \%$ 감소) 에서 유의한 변화가 나타났고, 운동 중 30분 $(147.00 \%$ 증가)에서 유의한 변화가 나타났다. PYA에서 안정시 혈 중 lactate 농도가 감소한 이유는 장시간 유산소 운동으 로 인한 glycogen 절약효과로 피로 관련 물질인 혈중 lactate 농도가 감소되었을 것으로 판단된다. 특히 PYA 의 운동 중 60 분의 결과를 함께 살펴보면 수치상 $5.3 \%$ 감소하였으며, 안정시는 PLA 보다 더욱 유의한 감소가 나타났다. 본 연구는 pyruvate 및 혈중 산소 농도 등의 측정은 실시하지 않았으나, pyruvate 섭취가 PYA의 안 정시 및 10 주간 운동 중 및 회복기에도 지속적으로 지방 대사를 촉진시켜 lactate를 에너지원으로 원활하게 공급 하는데 더욱 긍정적인 영향을 주었다고 사료된다. 이는 상대적으로 PLA보다 PYA에서 피로 시점을 지연시켜 운 동수행능력이 더욱 향상된 결과와도 관련이 있다고 본다. 한편 운동 중 30 분에 PYA에서 유의한 증가가 나타난 것 은 Diers et al.(2012)의 연구에서도 체내에 pyruvate가 축적되면 대사 과정에서 유입되지 못한 pyruvate는 lactate로 전환되어 높은 수준으로 증가될 수 있다고 보고 된 바 있다. 본 연구의 PYA는 10 주간 충분한 양의 $\mathrm{pyr}^{-}$ uvate가 체내에 축적되어 운동 중 30 분에는 높은 수준 으로 나타났다고 생각되며, 유산소 운동을 실시함에 따라 더욱 장시간 고강도에서도 유용한 에너지원으로 사용될 수 있다는 점에서 매우 중요한 의미가 있다.

체내 과도하게 축적된 지방은 높은 수준의 혈중 지질 을 유발하기 때문에 규칙적인 운동을 통한 관리가 요구된 다(Cai \& Zou, 2016). 한편 pyruvate와 혈중 지질 변화 에 관한 연구에서는 다양한 결과가 보고되었는데, Stanko et al. (1992)은 비만인에게 pyruvate를 투여한 결과 TC $4 \%, \mathrm{LDL}-\mathrm{C} 5 \%$ 가 감소하였고, 혈중 $\mathrm{TG}$ 와 $\mathrm{HDL}-\mathrm{C}$ 는 유 의한 변화가 없었다고 보고하였다. Koh-Banerjee et al. (2005)은 pyruvate 섭취군에서 HDL-C의 감소가 나타 났으며, 오히려 pyruvate 섭취가 혈중 지질에 부정적인 영향을 줄 수도 있다고 보고하였다. 최근에는 비만 여성 을 대상으로 혈중 TG, TC, HDL-C, 그리고 $\mathrm{LDL}-\mathrm{C}$ 를 비교한 결과 pyruvate 섭취군에서 혈중 $\mathrm{TG}, \mathrm{TC}$, 그리고 $\mathrm{LDL}-\mathrm{C}$ 의 감소가 나타났으며, $\mathrm{HDL}-\mathrm{C}$ 는 증가를 보였으 나 유의한 차이가 없었다는 연구 또한 보고되었다(Gong 
\& Jiang, 2018). 본 연구의 혈액변인 변화에서는 두 집 단 모두 10 주간의 처치 후 $\mathrm{TG}, \mathrm{TC}$, 그리고 $\mathrm{LDL}-\mathrm{C}$ 에서 유의한 변화가 나타나지 않았다. 이는 Imayama et al. (2012)의 연구에서도 체중의 $5 \%$ 이상 변화할 때 염증과 혈중 지질 변화가 나타날 수 있다고 보고하였는데, 본 연 구의 두 집단 모두 신체구성 변화에서 $5 \%$ 이상의 변화가 없었기 때문에 혈중 지질에서도 큰 변화는 나타나지 않 았을 것으로 사료된다. 다만 체중과 $\mathrm{BMI}$ 의 유의한 변화 가 나타났던 PYA의 혈중 지질은 수치상 모두 사전보다 개선되는 변화가 나타났으며, 이러한 결과는 장기적으로 신체구성의 긍정적인 변화와 함께 혈중 지질의 변화에도 긍정적인 영향을 미칠 수 있을 것이라 사료된다. 한편 $\mathrm{PLA}$ 에서는 $\mathrm{HDL}-\mathrm{C}(9.13 \%$ 감소)의 유의한 변화가 나 타났다. Keating et al. (2015)은 유산소 운동 시 HDL-C 의 증가를 위해서는 장기간 $70 \sim 80 \%$ 이상의 고강도를 실시하여야 한다고 보고하였다. 그러나 본 연구에서는 10 주간 체력 수준의 변화에도 상대적인 운동 강도는 50 $65 \%$ 중강도로 동일하게 실시하였기 때문에 $\mathrm{HDL}-\mathrm{C}$ 의 유의한 증가는 나타나지 않았을 것으로 판단된다. 다만 PYA에서는 HDL-C의 농도는 유의하지 않지만 다소 증 가된 것을 확인할 수 있다. 이는 앞서 언급된 Gong \& Jiang(2018)의 연구에서 비만여성을 상대로 한 실험의 pyruvate 섭취군의 혈중 $\mathrm{TG}, \mathrm{TC}$, 그리고 $\mathrm{LDL}-\mathrm{C}$ 의 감 소가 나타났으나 $\mathrm{HDL}-\mathrm{C}$ 는 증가를 보였으나 유의한 차 이가 없었던 결과와 같은 것으로 지속적인 운동이 실시되 었다면 유의한 변화를 관찰 할 수 있었을 것으로 사료된 다. 추후 연구에서 장기간의 운동과 다양한 운동 강도에 따른 변화를 살펴보아야 할 것이다.

한편 인슐린 저항성은 대사질환과 직접적으로 연관되 며, 특히 비만은 인슐린 저항성을 유발하는 주된 원인으 로 알려져 있다(Balsan et al., 2015). 국제 당뇨 협회 (international dibetes federation: IDF)는 HOMA-IR 의 인슐린 저항성 기준을 3.0 이상으로 제시하고 있으며, 본 연구에서 HOMA-IR은 PYA가 사전 2.7, PLA는 사전 3.1 으로 두 집단 모두 인슐린 저항성 위험 범주에 속해 있었다. Roberts et al. (2013)은 유산소 운동은 인슐린 저항성이 있는 비만인에게서 $25 \%$ 이상의 개선을 가져올 수 있으며, 장기간 높은 강도 운동에서 더욱 큰 효과가 나 타난다고 보고하였다. 본 연구의 두 집단 모두 Insulin과 HOMA-IR의 유의한 변화는 나타나지 않았으나 사전보 다 개선된 결과는 10 주간 규칙적인 유산소 운동의 효과
로서 비만인에게 매우 중요한 변화이며, 선행연구를 지지 하는 결과라고 할 수 있다. 그러나 10 주간 $50 \sim 65 \%$ 의 중강도 유산소 운동 처치가 유의한 변화를 가져오기에 다 소 짧은 기간일 수 있었으며, 선행연구에서도 Wu et al. (2017)은 12주간 비만인을 저강도, 중강도, 그리고 고강 도 운동그룹으로 나누고 주 3회 60분의 유산소 운동을 실 시한 결과 $\mathrm{HRR} 70 \sim 80 \%$ 고강도 운동그룹에서 Insulin 수치가 가장 많이 개선되었으며, $50 \sim 70 \%$ 중강도 운동 그룹에서도 Insulin 수치가 개선되는 경향이 나타났으 나, 고강도에서 가장 효과적이라고 보고하였다. 따라서 본 연구에서도 더욱 장기간 고강도로 실시하였다면 또 다른 변화가 나타났을 것으로 본다. 한편 지방조직에서 주로 발현되는 호르몬인 leptin은 시상하부 수용체와 결 합하여 식옥 억제 및 에너지 소비 조절 등에 관여한다 (Segura et al., 2015). 비만에 의한 체지방의 증가는 혈 중 leptin 수준을 증가시키는 주된 요인으로서, leptin 수용체의 저항을 증가시켜 Leptin 저항성을 유발한다고 보고되었다(Park \& Ahima, 2015). 따라서 비만 개선을 통한 지방조직의 감소는 leptin 수치를 낮추는 방법이며, 지방을 주 에너지원으로 사용하는 유산소 운동이 별다 른 부작용 없이 효과적인 방법이 될 수 있다(Hulver \& Houmard, 2003). Akbarpour(2013)은 규칙적인 유산소 운동이 혈중 leptin 수준을 개선하고, 체지방 감소나 유 산소 능력의 향상 등과 함께 심장 질환의 위험을 감소시 킨다는 점에서 비만 개선을 위한 비 약물 치료로 사용된 다고 하였다. 한편 pyruvate 섭취와 leptin의 변화를 알 아본 연구는 매우 부족한 실정으로 본 연구에서는 비만인 에게 10 주간 pyruvate 섭취와 유산소 운동이 비만 관련 호르몬인 leptin에 미치는 영향을 검증하고자 하였다. 10 주간 처치 후 PYA에서 leptin(32.64\% 감소)의 유의한 변화가 나타났다. 특히 PYA의 사전 leptin 수치가 PLA 의 수치 보다 높은 수치였음에도 사후에 더욱 유의한 감 소가 나타났다. 이러한 결과는 규칙적인 유산소 운동과 함께 PYA에서 체중 및 $\mathrm{BMI}$ 의 유의한 감소가 나타나 비 만 개선을 통해 leptin의 긍정적인 변화가 나타난 것으 로 판단된다. 이러한 결과는 유산소 운동이 leptin 수준 을 개선시키는데 효과적이라고 보고한 선행연구를 지지 하는 결과가 될 수 있다. 또한 비만인에게 대사 질환의 위 험을 감소시키는 긍정적인 변화로서 임상적으로 의미있 는 결과라고 사료된다. 종합해보면, 10 주간 pyruvate 섭 취로 인한 체내 축적이 유산소 운동시 지방 대사를 촉진 
시키는 에너지 전구체로서 더욱 긍정적인 영향을 주었기 때문이라는 결론을 내렸으며, PYA에서 신체구성의 개선 이 나타남에 따라 비만 개선을 통한 leptin의 유의한 감 소에도 긍정적인 영향을 미친 것으로 사료된다. 따라서 leptin은 비만과 밀접한 관련이 있는 호르몬이며, 본 연 구에서는 비만인에게 10 주간 pyruvate 섭취와 운동의 병행이 비만 개선과 leptin의 변화에 더욱 긍정적인 영향 을 줄 수 있음을 규명했다는 점에서 중요한 의미가 있다 고 본다.

\section{결 론}

본 연구의 결론은 다음과 같다.

1. 신체구성의 변화에 미치는 영향을 알아본 결과 $\mathrm{PYA}$ 에서 체중, $\mathrm{BMI}$, 체지방률, 그리고 체지방량이 감 소하였다.

2. 운동수행능력의 변화에 미치는 영향을 알아본 결과 $\mathrm{VO}_{2 \max }$ 는 PYA와 PLA 모두 증가하였다. 운동 중 거리의 경우 PYA와 PLA 모두 15 분에서 30 분까지의 거리가 증 가하였으며, 운동이 지속됨에 따라 PYA에서만 운동 중 45 분과 60 분 거리가 증가하였다.

3. 혈액변인 중 lactate 농도의 변화에 미치는 영향을 알아본 결과, $\mathrm{PYA}$ 에서 안정시에 유의하게 감소하고, 운 동 30 분 후 유의하게 증가하였지만, 45 분 후에는 유의한 차이가 나타나지 않았다.

4. 혈액변인 및 비만 관련 호르몬의 변화에 미치는 영 향을 알아본 결과 PLA에서 $\mathrm{HDL}-\mathrm{C}$ 는 감소하였으며, 비 만 관련 호르몬인 leptin은 PYA에서 감소하였다.

따라서 두 집단 모두에서 10 주간 지방 산화 비율이 가 장 높다고 보고된 $50 \sim 60 \%$ 중강도 유산소 운동은 비만 개선 효과가 있으며 운동수행능력에 긍정적 영향을 주는 것으로 나타났다. 특히 pyruvate를 섭취가 PLA 보다 신 체구성 및 비만 관련 호르몬인 leptin에도 더욱 긍정적인 결과를 가져왔다고 판단된다. 본 연구는 20 대 비만 남성 에게 선행연구들 보다 장기간 pyruvate 섭취와 운동을 병행하여 pyruvate 섭취가 비만 개선에 긍정적인 영향 을 미칠 수 있는 ergogenic aids임을 알아냈다는 점에서 큰 의미가 있다. 한편 대부분 사전 보다 개선되는 변화가
나타났으나 유의한 변화는 나타나지 않았던 혈중 지질 변 화는 10 주의 기간이 큰 변화를 가져오기에는 다소 짧은 기간이었을 수 있었으며, 실험 중 운동 수행능력 향상에 따른 운동 강도나 횟수 등에 변화를 주었다면 또 다른 결 과가 나타났을 것으로 사료된다. 따라서 추후 연구에서 는 장기간 pyruvate 섭취와 유산소 운동뿐만 아니라 저 항운동을 함께 병행하는 방법, 고강도의 인터벌 운동, 그 리고 더욱 장시간 중고강도 운동을 병행하는 훈련 등 다 양한 운동기간, 운동 방법, 운동 강도의 설정을 통해 효과 를 규명하는 후속 연구가 필요하다고 판단된다.

\section{참고문헌}

Akbarpour, M. (2013). The effect of aerobic training on serum adiponectin and leptin levels and inflammatory markers of coronary heart disease in obese men. Biology of Sport, 30(1), 21-27.

American College of Sports Medicine (2010). ACSM's Resource for Guidelines for Exercise Testing and Prescription. Lippincott Williams \& Wilkins: Baltimore, MD.

Arroyo-Johnson, C. \& Mincey, K. D.(2016). Obesity epidemiology worldwide. Gastroenterology Clinics, 45(4), 571-579.

Balsan, G. A., Vieira, J. L. D. C., Oliveira, A. M. D., \& Portal, V. L. (2015). Relationship between adiponectin, obesity and insulin resistance. Revista da Associacao Medica Brasileira, 61(1), 72-80.

Banks, W. A., Gertler, A., Solomon, G., Niv-Spector, L., Shpilman, M., Yi, X., Batrakova, E., Vinogrado, S., \& Kabanov, A. V. (2011). Principles of strategic drug delivery to the brain (SDDB): development of anorectic and orexigenic analogs of leptin. Physiology and Behavior, 105(1), 145-149.

Billat, L. V. \& Koralsztein, J. P. (1996). Significance of the velocity at $\mathrm{VO}_{2 \max }$ and time to exhaustion at this velocity. Sports Medicine, 22(2), 90-108.

Bruce, R. A., Blackmon, J. R., Jones, J. W., \& Strait, G. (2004). Exercising testing in adult normal subjects and cardiac patients. Annals of Noninvasive Electrocardiology, 9(3), 291303.

Cai, M. \& Zou, Z. (2016). Effect of aerobic exercise on blood lipid and glucose in obese or overweight adults: A metaanalysis of randomised controlled trials. Obesity Research and Clinical Practice, 10(5), 589-602.

Cortez, M. Y., Torgan, C. E., Brozinick, J. T., Miller, R. H., \& 
Ivy, J. L. (1991). Effects of pyruvate and dihydroxyacetone consumption on the growth and metabolic state of obese Zucker rats. The American Journal of Clinical Nutrition, 53(4), 847-853.

Diers, A. R., Broniowska, K. A., Chang, C. F., \& Hogg, N. (2012). Pyruvate fuels mitochondrial respiration and proliferation of breast cancer cells: effect of monocarboxylate transporter inhibition. Biochemical Journal, 444(3), 561-571.

Gladden, L. B. (2004). Lactate metabolism: a new paradigm for the third millennium. The Journal of Physiology, 558(1), 5-30.

Gong, W. \& Jiang, J. (2018). Effect of rope skipping combining calcium pyruvate on fat metabolism of female college students. Biomedical Research, 29, 333-336.

Gray, L. R., Tompkins, S. C., \& Taylor, E. B. (2014). Regulation of pyruvate metabolism and human disease. Cellular and Molecular Life Sciences, 71(14), 2577-2604.

Hermann, H. P., Arp, J., Pieske, B., Kögler, H., Baron, S., Janssen, P. M., \& Hasenfuss, G. (2004). Improved systolic and diastolic myocardial function with intracoronary pyruvate in patients with congestive heart failure. European Journal of Heart Failure, 6(2), 213-218.

Heyward, V. H. \& Gibson, A. (2014). Advanced Fitness Assessment and Exercise Prescription, 7th edition. Human Kinetics.

Hulver, M. W. \& Houmard, J. A. (2003). Plasma leptin and exercise. Sports Medicine, 33(7), 473-482.

Imayama, I., Ulrich, C. M., Alfano, C. M., Wang, C., Xiao, L., Wener, M. H., Campbell, K. L., Duggan, C., Foster-Schubert, K. E., Kong, A., Mason, C. E., Wang, C. Y., Blackburn, G. L., Bain, C. E., Thompson, H. J., \& Tiernan, A. M. (2012). Effects of a caloric restriction weight loss diet and exercise on inflammatory biomarkers in overweight/obese postmenopausal women: a randomized controlled trial. Cancer research, 72(9), 2314-2326.

Kalman, D., Colker, C. M., Wilets, I., Roufs, J. B., \& Antonio, J. (1999). The effects of pyruvate supplementation on body composition in overweight individuals. Nutrition, 15(5), 337-340.

Keating, S. E., Hackett, D. A., Parker, H. M., O’Connor, H. T., Gerofi, J. A., Sainsbury, A., Baker, M. K., Chuter, V. H., Caterson, L. D., George, J., \& Johnson, N. A. (2015). Effect of aerobic exercise training dose on liver fat and visceral adiposity. Journal of Hepatology, 63(1), 174-182.

Koh-Banerjee, P. K., Ferreira, M. P., Greenwood, M., Bowden, R. G., Cowan, P. N., Almada, A. L., \& Kreider, R. B. (2005).
Effects of calcium pyruvate supplementation during training on body composition, exercise capacity, and metabolic responses to exercise. Nutrition, 21(3), 312-319.

Koivisto, H., Leinonen, H., Puurula, M., Hafez, H. S., Barrera, G. A., Stridh, M. H., Waagepetersen, H., S., Tiainen, M., Soininen, P., Zilberter, Y., \& Tanila, H. (2016). Chronic pyruvate supplementation increases exploratory activity and brain energy reserves in young and middle-aged mice. Frontiers in Aging Neuroscience, 8, 41.

Ledee, D. R., Kajimoto, M., O'Kelly Priddy, C. M., Olson, A. K., Isern, N., Robillard-Frayne, I., Rosiers, C. D., \& Portman, M. A. (2015). Pyruvate modifies metabolic flux and nutrient sensing during extracorporeal membrane oxygenation in an immature swine model. American Journal of PhysiologyHeart and Circulatory Physiology, 309(1), 137-146.

Lee, M. G., Sedlock, D. A., Flynn, M. G., \& Kamimori, G. H. (2009). Resting metabolic rate after endurance exercise training. Medicine and Science in Sports and Exercise, 41(7), 1444-1451.

Lundsgaard, A. M., Fritzen, A. M., \& Kiens, B. (2017). Molecular Regulation of Fatty Acid Oxidation in Skeletal Muscle during Aerobic Exercise. Trends in Endocrinology and Metabolism, 29(1), 18-30.

McMurray, R. G., Soares, J., Caspersen, C. J., \& Mccurdy, T. (2014). Examining variations of resting metabolic rate of adults: a public health perspective. Medicine and Science in Sports and Exercise, 46(7), 1352-1358.

Milanović, Z., Sporiš, G., \& Weston, M. (2015). Effectiveness of high-intensity interval training (HIT) and continuous endurance training for $\mathrm{VO}_{2 \max }$ improvements: a systematic review and meta analysis of controlled trials. Sports Medicine, 45(10), 1469-1481.

Ministry of Health and Welfare (2015). National Health Statistics.

Morrison, M. A., Spriet, L. L., \& Dyck, D. J. (2000). Pyruvate ingestion for 7 days does not improve aerobic performance in well-trained individuals. Journal of Applied Physiology, $89(2), 549-556$

Motamedi, P., Nikroo, H., \& Hejazi, K. (2017). The Effects of Eight-Weeks Aerobic Training on Serum Leptin Levels, Anthropometric Indices and $\mathrm{VO}_{2 \max }$ in Sedentary Obese Men. Journal of Ergonomics, 5(1), 36-42.

Naderi, A., Earnest, C. P., Lowery, R. P., Wilson, J. M., \& Willems, M. E. (2016). Co-ingestion of nutritional ergogenic aids and high-intensity exercise performance. Sports Medicine, 46(10), 1407-1418. 
Nybo, L., Sundstrup, E., Jakobsen, M. D., Mohr, M., Hornstrup, T., Simonsen, L., Bulow, J., Randers, M. R., Nielsen, J. J., Aagaard, P., \& Krustrup, P. (2010). High-intensity training versus traditional exercise interventions for promoting health. Medicine and Science in Sports and Exercise, 42(10), 1951-1958.

Olek, R. A., Kujach, S., Wnuk, D., \& Laskowski, R. (2014). Single sodium pyruvate ingestion modifies blood acid-base status and post-exercise lactate concentration in humans. Nutrients, 6(5), 1981-1992.

Onakpoya, I., Hunt, K., Wider, B., \& Ernst, E. (2014). Pyruvate supplementation for weight loss: a systematic review and meta-analysis of randomized clinical trials. Critical Reviews in Food Science and Nutrition, 54(1), 17-23.

Park, H. K. \& Ahima, R. S. (2015). Physiology of leptin: Energy homeostasis, neuroendocrine function and metabolism. Metabolism Clinical and Experimental, 64(1), 24-34.

Proia, P., Di Liegro, C. M., Schiera, G., Fricano, A., \& Di Liegro, I. (2016). Lactate as a Metabolite and a Regulator in the Central Nervous System. International Journal of Molecular Sciences, 17(9), 1450-1470.

Roberts, C. K., Hevener, A. L., \& Barnard, R. J. (2013). Metabolic syndrome and insulin resistance: Underlying causes and modification by exercise training. Comprehensive Physiology, $3(1), 1-58$.

Saper, R. B., Eisenberg, D. M., \& Phillips, R. S. (2004). Common dietary supplements for weight loss. American Family Physician, 70, 1731-1740.

Schell, J. C., Olson, K. A., Jiang, L., Hawkins, A. J., Van Vranken, J. G., Xie, J., Egnatchik, R. A., Earl, E. G., DeBerardinis, R. J., \& Rutter, J. (2014). A role for the mitochondrial pyruvate carrier as a repressor of the Warburg effect and colon cancer cell growth. Molecular Cell, 56(3), 400-413.
Segura, S., Efthimiadi, L., Porcher, C., Courtes, S., Coronas, V., Krantic, S., \& Moyse, E. (2015). Leptin-dependent neurotoxicity via induction of apoptosis in adult rat neurogenic cells. Frontiers in Cellular Neuroscience, 9, 350-350.

Spradley, B. D., Crowley, K. R., Tai, C. Y., Kendall, K. L., Fukuda, D. H., Esposito, E. N., Moon, S. E., \& Moon, J. R. (2012). Ingesting a pre-workout supplement containing caffeine, B-vitamins, amino acids, creatine, and beta-alanine before exercise delays fatigue while improving reaction time and muscular endurance. Nutrition and Metabolism, 9(1), 1-9.

Stanko, R. T., Reynolds, H. R., Lonchar, K. D., \& Arch, J. E. (1992). Plasma lipid concentrations in hyperlipidemic patients consuming a high-fat diet supplemented with pyruvate for $6 \mathrm{wk}$. The American Journal of Clinical Nutrition, 56(5), 950-954.

Swift, D. L., Johannsen, N. M., Lavie, C. J., Earnest, C. P., \& Church, T. S. (2014). The role of exercise and physical activity in weight loss and maintenance. Progress in Cardiovascular Diseases, 56(4), 441-447.

Wauman, J., Zabeau, L., \& Tavernier, J. (2017). The Leptin Receptor Complex: Heavier Than Expected. Frontiers in Endocrinology, 8, 30.

Wu, L. S., Ko, M. C., Ho, C. C., Lee, P. F., Chen, L. Y., \& Tseng, C. Y. (2017). Response of insulin resistance indicators to aerobic exercise at different intensities in obese college students. World Academy of Science, Engineering and Technology, International Journal of Sport and Health Sciences, 11(5), 514.

Zhang, Y., Proenca, R., Maffei, M., Barone, M., Leopold, L., \& Friedman, J. M. (1994). Positional cloning of the mouse obese gene and its human homologue. Nature, 372(6505), 425 . 


\section{Pyruvate 섭취와 유산소 운동이 비만 남성의 혈청 요인에 변화와 신체구성에 미치는 영향}

\section{조현정 - 백일영 - 김지수 - 김대은(연세대학교)}

[목적〕 본 연구는 20 대 비만 남성을 대상으로 10 주간 pyruvate 섭취와 유산소 운동이 신체구성, 운동수행 능력, 그리고 혈액변인 및 비만 관련 호르몬에 미치는 영향을 검증하여, 비만 개선에 효과적인 물질로서 pyruvate 섭취 효과 및 유산소 운동의 효과를 규명하고자 하였다. 〔방법) 본 연구의 대상자는 BMI $25 \mathrm{~kg} / \mathrm{m}^{2}$ 이상과 체지방률 $25 \%$ 이상에 해당되는 20 대 비만 남성 20 명을 선정하였으며, pyruvate 섭취와 유산소 운동 집단(PYA) 10 명, 위약 섭취와 유산소 운동 집단(PLA) 10 명으로 무선배정 하였다. pyruvate와 위약 섭취 는 각각 10 주간 하루 $6 \mathrm{~g}$ 씩 매일 섭취하였으며, 유산소 운동은 10 주간 주 3 회, 하루 60 분간의 트레드밀 운동 을 목표심박수 $50 \sim 65 \%$ 강도로 실시하였다. pyruvate 섭취 효과 및 유산소 운동의 효과를 규명하기 위하 여 신체구성, 운동수행능력, Lactate, 그리고 혈액변인 및 비만 관련 호르몬을 사전과 사후 모두 동일한 방법 으로 측정하였다. 〔결과〕 본 연구에서 얻은 주요 결과는 다음과 같다. 1) 신체구성의 경우 PYA에서 체중 $(p$ 〈 $.01), \operatorname{BMI}(p<.05)$, 체지방률 $(p<.01)$, 그리고 체지방량 $(p<.001)$ 이 유의하게 감소하는 것으로 나타났다. 2 ) 운동수행능력은 $\mathrm{VO}_{2 \max }$ 의 경우 $\mathrm{PYA}(p<.01)$ 와 $\mathrm{PLA}(p<.001)$ 모두 유의하게 증가하였으며, 또한 운동 중 거리의 경우 15 분에서 $\operatorname{PYA}(p<.01)$ 와 $\operatorname{PLA}(p<.05), 30$ 분에서 $\operatorname{PYA}(p<.01)$ 와 $\operatorname{PLA}(p<.05)$ 유의하 게 증가되었으나, 45분 $p<.01)$ 부터 60( $p<.05)$ 분까지는 PYA에서만 유의하게 증가하는 것으로 나타났다. 3) Lactate의 경우 안정시 $\operatorname{PYA}(p<.001)$ 에서 유의하게 감소하고, 운동 30 분 후 $\operatorname{PYA}(p<.001)$ 에서 유의 하게 증가하였지만 45 분 후에는 유의한 차이가 나타나지 않았다. 4 ) 혈액변인의 경우 HDL-C의 경우 PLA( $p$ <.05)에서 유의하게 감소되는 것으로 나타났으며, Leptin의 경우 PYA( $p<.001)$ 에서 유의하게 감소되는 것으로 나타났다. 〔결론) 이상의 본 연구 결과를 요약하면, 동일한 유산소 운동을 실시하더라도 pyruvate를 섭취한 PYA가 비만 개선에 더욱 효과적인 것으로 나타났다.

주요어: 비만, 피루빈산, 유산소 운동, 운동부하검사, 젖산, 렙틴 